\title{
Fermentative losses and chemical composition and in vitro digestibility of corn grain silage rehydrated with water or acid whey combined with bacterial-enzymatic inoculant
}

\section{Perdas fermentativas e composição química e digestibilidade in vitro da silagem de milho reidratada com água ou soro de leite associada com inoculante bacteriano-enzimático}

Fernanda Naiara Fogaça da Cruz ${ }^{*}$; Flávio Pinto Monção²; Vicente Ribeiro Rocha Júnior'; Amanda Maria Silva Alencar'; João Paulo Sampaio Rigueira ${ }^{3}$; Ariadne Freitas Silva ${ }^{1}$; Renan Lucas Miorin ${ }^{4}$; Ana Cláudia Maia Soares ${ }^{5}$; Cinara da Cunha Siqueira Carvalho3; Carlos Juliano Brant Albuquerque ${ }^{3}$

\section{Highlights}

Acid whey has great potential to be used in the ensiling process of corn grain.

Silage rehydration it is strategy to avoid discarding acid whey in the ambient.

The bacterial-enzymatic inoculant reduces dry matter losses from silage.

\section{Abstract}

This study aimed to evaluate the effects of rehydration with water or acid whey, as well as the effects of bacterial-enzymatic inoculant on fermentation losses, aerobic stability, and chemical composition and in vitro digestibility of corn grain silages. The treatments consisted of corn kernels (Zea mays) ground through a $3-\mathrm{mm}$ sieve and rehydrated with chlorine-free water or unsalted whey $(\mathrm{NaCl})$ combined or not with bacterialenzymatic inoculant. This was a $2 \times 2$ factorial completely randomized design with sources of rehydration (water or whey) and absence and presence of bacterial-enzymatic inoculant with eight replications. Water

1 Students of Animal Science Master's Course, Universidade Estadual de Montes Claros, UNIMONTES, Janaúba, MG, Brazil. E-mail: fogaca.fernandaa@gmail.com; amandaalencar604@gmail.com; ariadnefreitassilva@yahoo.com.br

2 Prof. and Researcher PNPD/Capes, Postgraduate Program in Animal Science (Master), UNIMONTES, Janaúba, MG, Brazil. E-mail: moncaomoncao@yahoo.com.br

${ }^{3}$ Profs. Drs., Postgraduate Program in Animal Science (Master), UNIMONTES, Janaúba, MG, Brazil. E-mail: vicente. rocha@unimontes.br; joao.rigueira@unimontes.br; cinara.carvalho@unimontes.br; carlosjuliano@ufmg.br

${ }^{4}$ Prof. EBTT, Dr., Instituto Federal do Mato Grosso, IFMT, Guarantã do Norte, MT, Brazil. E-mail: renan.miorin@gta.ifmt. edu.br

${ }^{5}$ Dra. in Animal Science, PLM Representation in Animal Nutrition, Janaúba, MG, Brazil. E-mail: anacmszootecnista@ gmail.com

* Author for correspondence

Received: Apr. 17, 2021 - Approved: June 30, 2021 
and acid whey were added to ground corn with $12 \%$ moisture in order to increase it to $35 \%$. Rehydrated corn was ensiled in Polyvinyl chloride (PVC) minisilos and stored for $60 \mathrm{~d}$. The bacterial-enzymatic inoculant used was composed of Lactobacillus curvatus, L. acidophilus, L. plantarum, L. buchneri, L. lactis, Pediococcus acidilactici, Propionibacterium acidipropionici and Enterococcus faecium, in concentrations of $10^{10} \mathrm{CFU} \mathrm{g}^{-1}$ and $5 \%$ cellulose-based enzyme complex. The aerobic exposure of silages was evaluated for 120 hours. There was interaction $(P=0.02)$ between the sources of rehydration and the use or not of the inoculant on the values of silage temperature during aerobic exposure. There was a difference for dry matter (DM) losses $(P=0.38)$ between rehydrated corn silages with and without inoculant. DM losses were $37.51 \%$ higher in silage without inoculant compared to silage with inoculant (3.84\% DM). There was no difference between the sources of rehydration on DM losses $(P=0.39)$, with a mean value of $4.99 \%$. Corn rehydration using acid whey $(\mathrm{P}<0.01)$ increased $2.19 \%$ and $31.36 \% \mathrm{DM}$ and ash content compared to water, an average of $66.14 \%$ and $1.28 \%$, respectively. There was no interaction $(P=0.30)$ between the sources of rehydration and the use of inoculants on the in vitro digestibility of DM (mean of 79.26\%). The use of the bacterial-enzymatic inoculant improved the fermentation characteristics, aerobic stability and nutritional value of corn grain silage rehydrated with water or whey.

Key words: Aerobic stability. Dry matter recovery. Rehydrated corn grain silage. acid whey. Fermentation.

\section{Resumo}

Objetivou-se avaliar se os efeitos da reidratação com água ou soro de leite ácido, bem como os efeitos da inoculação enzimático-bacteriano influenciam as perdas fermentativas, estabilidade aeróbia e composição química e digestibilidade in vitro de silagens de grãos de milho. Os tratamentos consistiram dos grãos de milho (Zea mays) moídos na peneira de $3 \mathrm{~mm}$ e reidratados com água sem cloro ou soro leite sem sal ( $\mathrm{NaCl}$ ) associado ou não com inoculante bacteriano-enzimático. Foi utilizado o delineamento inteiramente casualizado em esquema fatorial $2 \times 2$, sendo fontes de reidratação (água ou soro de leite) e ausência e presença de inoculante enzimático-bacteriano com oito repetições. Aágua e soro de leite foram adicionados no milho moído com $12 \%$ de umidade visando aumentar para 35\%. O milho reidratado foi ensilado em minisilos de Polyvinyl chloride (PVC) e armazenado durante 60 dias. 0 inoculante enzimático-bacteriano utilizado foi composto por Lactobacillus curvatus, L. acidophilus, L. plantarum, L. buchneri, L. lactis, Pediococcus acidilactici, Propionibacterium acidipropionici e Enterococcus faecium, em concentrações de $10^{10} \mathrm{UFC} \mathrm{g}^{-1}$ e $5 \%$ de complexo enzimático à base de celulose. A exposição aeróbia das silagens foi avaliada durante 120 horas. Houve interação $(P=0,02)$ das fontes de reidratação e uso ou não do inoculante sobre os valores da temperatura da silagem durante exposição aeróbia. Houve diferença entre as silagens de milho reidratado sem e com inoculante sob as perdas de matéria seca (MS) $(P=0,38)$. As perdas de $M S$ foi 37,51\% superior na silagem sem inoculante em comparação a silagem com inoculante (média de 3,84\% da MS). Não houve diferença entre as fontes de reidratação sobre as perdas de MS $(P=0,39)$, média de 4,99\%. A reidratação do milho usando soro ácido $(P<0,01)$ aumentou $2,19 \%$ e 31,36\% no teor de MS e cinzas em comparação à água, média de $66,14 \%$ e 1,28\%, respectivamente. Não houve interação $(P=0,30)$ entre as formas de reidratação e o uso de inoculantes sobre a digestibilidade in vitro da MS (média de 79,26\%). O uso do inoculante enzimático bacteriano melhorou as características fermentativas, estabilidade aeróbia e valor nutricional da silagem de grãos de milho reidratada com água ou soro de leite.

Palavras-chave: Estabilidade aeróbia. Recuperação de matéria seca. Silagem de grão de milho reidratada. Soro de leite ácido. Fermentação. 


\section{Introduction}

Corn (Zea mays L.) is one of the main ingredients used in ruminant diets to increase energy levels and animal performance (Bernardes \& Rêgo, 2014; Mombach, Pereira, Pina, Bolson, \& Pedreira, 2019; Daniel, Bernardes, Jobim, Schmidt, \& Nussio, 2019). This is related to the chemical composition that contains $879.6 \mathrm{~g} \mathrm{~kg}^{-1}$ dry matter, $205.1 \mathrm{~g}$ $\mathrm{kg}^{-1}$ water-soluble carbohydrates and 714.5 $\mathrm{g} \mathrm{kg}^{-1}$ starch (Valadares et al., 2016). In the semi-arid region of Brazil, it is not common to grow large amount of corn for grain production. Thus, farms do not have adequate structures for storing corn and other cereals for use in animal feed throughout the year. The consequence of this lack of structure for storing grains is the damage caused by rodents, insects and fungi (Mombach et al., 2019). rehydrated (reconstituted) Thus, corn grain silage has been used to circumvent these losses (C. M. Silva et al., 2016), and to improve the starch digestibility of corn (Ferraretto, Silva, Fernandes, Kim, \& Sultana, 2018) and nutrient utilization by ruminants (Castro et al., 2019; Jacovaci, Salvo, Jobim, \& Daniel, 2021). Furthermore, the technique of ensiling corn grain or another cereal makes it possible to purchase this ingredient at times with lower market costs, which is essential on farms and, especially, in the semi-arid region.

However, the low moisture content and soluble sugars in corn grain do not favor the fermentation inside the silo. In this context, rehydration of corn grains to achieve adequate moisture content to improve fermentation is a good strategy to reduce the risks in silage (Rezende et al., 2014). Water has been used to rehydrate ground corn during ensiling.
In turn, whey, the main by-product from cheese production in dairy industry, has great potential as a vehicle for rehydration (Rezende et al., 2014). The composition of the acid whey released from the clot during cheese making has about $94.86 \%$ water, $0.51 \%$ crude protein, $4.30 \%$ lactose, $0.55 \%$ minerals and vitamins, $0.10 \%$ fat and $\mathrm{pH}$ of 5.4 (Rezende et al., 2016). According to the same authors, this strategy of using whey would avoid serious environmental problems because acid whey is rich in various nutrients and cannot be disposed into watercourses or lakes.

Another method to reduce the risks associated with corn grain silage is the use of enzymatic-bacterial inoculant that contains several strains of homofermentative and/or heterofermentative bacteria and an enzyme complex containing cellulose and hemicellulose (Rezende et al., 2014; Jesus et al., 2021). Inside the silo, these strains of lactic acid bacteria rapidly produce large amounts of lactic and acetic acids, decreasing the silage pH (Muck et al., 2018) improving the conservation of nutrients. In addition, acetic acid produced under special circumstances inhibits the growth of fungi and yeasts, as well as improve aerobic stability (Muck et al., 2018). Thus, evaluating the rehydration of corn with acid whey combined with the use of enzymaticbacterial inoculant on the fermentation characteristics and nutritional value of silage is fundamental in rural properties.

Based on the above, the objective was to evaluate the effects of rehydration with water or acid whey, as well as the effects of enzymatic-bacterial inoculation on fermentation losses, aerobic stability, chemical composition and in vitro digestibility of corn grain silages. 


\section{Material and Methods}

All animal handling procedures were approved by the Animal Care and Ethics Committee of the State University of Montes Claros, Brazil (protocol 155/2019).

The experiment was carried out at Experimental Farm, State University of Montes Claros, Janaúba Campus (geographical coordinates: $15^{\circ} 52^{\prime} 38^{\prime \prime} \mathrm{S}, 43^{\circ} 20^{\prime} 05^{\prime \prime} \mathrm{W}$ ). The average annual rainfall at the site is less than $800 \mathrm{~mm}$, with an average annual temperature of $28{ }^{\circ} \mathrm{C}$ and a relative humidity of approximately $65 \%$. The climate of the region is BSh, according to the Köppen-Geiger classification.

Corn hybrid RB-8061 (Seeds KWS Riber, Patos de Minas, Brazil) was harvested when the grain moisture content was $12 \%$ (flint corn). Corn kernels were first ground to a particle size of $3 \mathrm{~mm}$ (Crusher/Disintegrator DPM-2, Nogueira®, São João da Boa Vista - SP - Brazil; 3mm sieve). During ensiling, ground corn was rehydrated with clean water without chlorine or unsalted whey ( $\mathrm{NaCl}$ ) combined or not with bacterial-enzymatic inoculant. Acid whey was obtained from a cheese maker. The amounts of acid whey and water needed to reach the established moisture level of 35\% (Rezende et al., 2014) were calculated with the following equation:

$\Delta$ Liquid $(\mathrm{L})=[\mathrm{MU} \times(\mathrm{FM}-\mathrm{IM}) / 100-\mathrm{FM}] /$ $\mathrm{SM}$, where $\mathrm{MU}=$ mass of the moisture product $(\mathrm{kg}), \mathrm{FM}=$ final moisture, $\mathrm{IM}=$ initial moisture and $\mathrm{SM}=$ specific mass of the liquid $\left(\mathrm{kg} \mathrm{L}^{-1}\right)$.

Rehydration with water or whey was performed in a single heap per treatment, which was later divided between replicates. The lyophilized enzymatic-bacterial inoculant (SILOTRATO ${ }^{\circledR}$ ) was sprayed according to the manufacturer's recommendations. The enzymatic-bacterial inoculant was composed of Lactobacillus curvatus, $L$. acidophilus, $L$. plantarum, L. buchneri, L. lactis, Pediococcus acidilactici, Propionibacterium acidipropionici, and Enterococcus faecium, in concentrations of $10^{10} \mathrm{CFU} \mathrm{g}{ }^{-1}$ ( $2 \mathrm{~g}$ product per ton of natural mass of corn) and 5\% enzymatic complex based on cellulose. Warranty levels were met by the manufacturer. The same amount of water was applied to the control silage. The chemical composition of corn and acid whey used, fresh, can be seen in Table 1. 
Table 1

Chemical composition of corn grain and whey, fresh

\begin{tabular}{|c|c|}
\hline Item & Corn, $\mathrm{g} \mathrm{kg}^{-1}$ dry matter \\
\hline Dry matter & 897.2 \\
\hline Ash & 15.4 \\
\hline Crude protein & 104.2 \\
\hline Neutral detergent fiber & 35.0 \\
\hline Total carbohydrates & 845.3 \\
\hline Non-fiber carbohydrates & 678.4 \\
\hline \multirow[t]{2}{*}{ Total digestible nutrients } & 861.1 \\
\hline & Acid whey \\
\hline $\mathrm{pH}$ & 5.33 \\
\hline Acidity ( $\left.{ }^{\circ} \mathrm{D}\right)$ & 28 \\
\hline Density $15^{\circ} \mathrm{C}$ & 1.024 \\
\hline Dry matter, g/kg as fed & 72.75 \\
\hline Fat (\%) & 0.40 \\
\hline Lactose (\%) & 4.62 \\
\hline Protein (\%) & 0.76 \\
\hline Ash (\%) & 0.43 \\
\hline Total solids 1 (\%) & 6.74 \\
\hline Total solids 2 (\%) & 6.21 \\
\hline
\end{tabular}

Total solids $1=$ Practical formula (using values of density and fat); Total solids $2=$ using oven drying.

The levels of water and acid whey were mixed with the grains, which were ensiled in experimental minisilos made of Polyvinyl chloride (PVC) tubes with a capacity of $3.92 \mathrm{~L}$ (eight minisilos per treatment), obtaining a final density of $1,025 \pm 50 \mathrm{~kg}$ corn grain $/ \mathrm{m}^{3}$. Silos were stored in a room and remained closed for $60 \mathrm{~d}$. After opening, the total dry matter losses (DML) from silages were quantified by the difference in weight of the set and ensiled mass, according to Jobim, Nussio, Reis and Schmidt (2007).

Aerobic stability was determined by placing a sample of silage (approximately $3 \mathrm{~kg}$ ) in a minisilo and kept in a non-air-conditioned room with varying temperature $\left(23.5-28.5^{\circ} \mathrm{C}\right)$.
Silage temperature was measured every eight hours using a data logger placed at the center of the mass for five days. Room temperature was also measured using a data collector placed near the mini-silos. Aerobic stability was defined as the number of hours that silage temperature remained stable before increasing by more than $2{ }^{\circ} \mathrm{C}$ above room temperature (Kung, Shaver, Grant, \& Schmidt, 2018). The $\mathrm{pH}$ was determined in the silage extract upon silo opening with a potentiometer (Ak 90, Akso Measuring Instruments, São Leopoldo, RS, Brazil).

A portion of the silages was predried in a forced ventilation oven at $55^{\circ} \mathrm{C}$. Subsequently, all samples were ground in a 
knife mill with a $1 \mathrm{~mm}$ mesh sieve for laboratory analysis. Part of the samples was ground in a 2 $\mathrm{mm}$ mesh sieve for in vitro digestibility analysis. Samples were analyzed for dry matter content (INCT-CA G-001/1 and G-003/1), crude protein (INCT-CA N-001/1), ether extract (INCT-CA G-005/1), and ash (INCT-CA M-001/1), neutral detergent fiber (NDF; INCT-CA F-002/1) and acid detergent fiber (ADF; INCT-CA F-003/1) by the conventional method using non-woven fabric; lignin (INCT-CA F-005/1) and nonfiber carbohydrates, according to Detmann et al. (2012). The content of total digestible nutrients (TDN) was estimated according to National Research Council [NRC] (2001).

The in vitro digestibility of DM, organic matter, crude protein, neutral detergent fiber and acid detergent fiber were determined according to Tilley and Terry (1963). The technique was modified with the use of in vitro incubator Tecnal ${ }^{\circledR}$ (TE-150), using non-woven fabric $\left(100 \mathrm{~g} \mathrm{~m}^{-2}\right)$ for making the incubation bag $(7.5 \times 7.5 \mathrm{~cm})$, according to Valente et al. (2011). To analyze the indigestible fraction of dry matter, NDF and ADF, silage samples were placed in non-woven fabric bags (100 weight and 50 microns) and incubated in the rumen for 288 h (Detmann et al., 2012), method INCT- CA F-008/1. For incubation, two adult crossbred cattle (Holstein/Zebu) were used, weighing $580 \pm 30 \mathrm{~kg}$, mean age of eight years, cannulated in the rumen. Before incubation, animals were adapted for 30 days to a diet containing corn silage and concentrate with $18 \%$ crude protein and $75 \%$ total digestible nutrients. The forage: concentrate ratio was 75:25 on a dry matter basis.

A principal component analysis (PCA) was applied to better understand the nature of the relationship between the studied variables and theindependentvariables. For thisanalysis,
13 characteristics studied were considered. Based on the correlation matrix between the characteristics, data were subjected to PCA, in which the variables were standardized to mean equal to zero and variance equal to one. A correlation matrix was used instead of a covariance matrix (Johnson \& Wichern, 2007). The method proposed by Kaiser (1960) was used to select which principal components best simplified the variability present in the data set and to compose the other analyses and interpretations. In this method, eigenvalues equal to or greater than one (1) were retained, since the original variables also show variance equal to one, after being standardized. For variables to be compared, new standardized variables were created from the original ones, as follows:

$$
\mathrm{Vp}=(\mathrm{V}-\mathrm{x}) / \sigma,
$$

where:

$\mathrm{Vp}=$ new weighted variable;

$\mathrm{V}=$ observed variable;

$x=$ mean of observations of the original variable;

$\sigma=$ standard deviation of the observed variable.

In the PCA, each principal component (Yi) corresponds to a linear combination of the 13 standardized variables (Xj) and these combinations are not correlated with each other:

$\mathrm{Y}_{i}=a_{i 1} \mathrm{X}_{1}+a_{i 2} \mathrm{X}_{2}+\ldots+a_{i p} \mathrm{X}_{p}=\sum_{j=1}^{p} a_{i j} \mathrm{X}_{j}$

$\mathrm{a}_{\mathrm{ij}}$ are the eigenvectors, with $\mathrm{i}=1,2, \mathrm{p}$ and $\sum_{j=1}^{p} a_{i j}^{2}=1$, where:

The first principal component, $\mathrm{Y}$ 1, has maximum variance among all linear combinations of $X$. The second principal component is not correlated with the first and 
has the second largest variance, and so on. For principal main component $Y i$, there is $p$ eigenvalue $(\lambda)$ ordered so that:

$$
\lambda_{1} \geq \lambda_{2} \geq \ldots
$$

The relative importance of a principal component was assessed based on the percentage of total variance explained, that is, the percentage of its eigenvalue in relation to the total eigenvalue of all components, given by:

$$
\mathrm{Yi}=\frac{\operatorname{Var}\left(\mathrm{Y}_{i}\right)}{\sum_{i=1}^{p} \operatorname{Var}\left(\mathrm{Y}_{i}\right)} \times 100=\frac{\lambda_{i}}{\sum_{i=1}^{p} \lambda_{i}} \times 100
$$

The interpretation of each of the selected principal components was made according to the variables with the highest weighting coefficients (eigenvectors), in absolute value. There is no specific value in the literature that determines when a weighting coefficient is important, so these values were interpreted according to the relationship between the characteristics within each component.

\section{A $2 \times 2$ factorial completely randomized} design was used, being sources of rehydration (water or acid whey) and absence and presence of enzymatic-bacterial inoculant, with eight replications. Data were subjected to analysis of variance. The Shapiro-Wilk test and the Bartlett test were applied to examine the normality of residuals and homoscedasticity of variance, respectively. Variables related to fermentation profile and nutritional values were analyzed according to the model:

$$
Y_{i j k}=\mu+R_{i}+I_{j}+R_{i} \times I_{1}+e_{i j k}
$$

where:

$\mathrm{Y}_{\mathrm{ijk}}=$ observation regarding the source of rehydration in plot " $\mathrm{i}$ " in the absence and presence of the inoculant in plot "j" in repetition "k";

$\mu=$ constant associated with all observations;

$\mathrm{R}_{\mathrm{i}}=$ effect of rehydration source " $\mathrm{i}$ ", with $\mathrm{i}=1$ and 2;

$\mathrm{I}_{\mathrm{j}}=$ effect of the absence and presence of inoculant " $\mathrm{j}$ ", with $\mathrm{i}=1$ and 2 ;

$\mathrm{R}_{\mathrm{i}} \times \mathrm{I}_{\mathrm{j}}=$ effect of the interaction of level "i" of the rehydration source with level " $\mathrm{j}$ " of the inoculant;

$e_{i \mathrm{jk}}=$ experimental error associated with plots that hypothetically have a normal distribution with zero mean and variance $\delta^{2}$.

Silage aerobic stability was analyzed following a completely randomized design with repeated measures over time with four treatments and six times after opening with six replications. The following statistical model was used:

$$
\begin{aligned}
Y_{i j k l}=\mu+R_{i}+I_{j}+ & T_{k}+R_{i} \times I_{j}+R_{i} \times T_{k}+I_{j} \times T_{k}+R_{i} \\
& \times I_{j} \times T_{k}+e_{i j k l}
\end{aligned}
$$

Where:

$\mathrm{Y}_{\mathrm{ijk}}=$ observation regarding the source of rehydration " $i$ " in the absence and presence of the inoculant " $\mathrm{j}$ " in repetition "I";

$\mu=$ constant associated with all observations; $\mathrm{R}_{\mathrm{i}}=$ effect of rehydration source " $\mathrm{i}$ ", with $\mathrm{i}=1$ and 2;

$\mathrm{I}_{\mathrm{j}}=$ effect of the absence and presence of inoculant " $\mathrm{j}$ ", with $\mathrm{i}=1$ and 2;

$\mathrm{T}_{\mathrm{k}}=$ effect of time after opening the silo " $\mathrm{k}$ ", with $\mathrm{k}=1,2,3,4,5$ and 6;

$R_{i} \times I_{j}=$ effect of the interaction of level "i" of the rehydration source with level " $j$ " of the inoculant;

$R_{i} \times T_{k}=$ effect of the interaction of level "i" of 
the rehydration source with level " $k$ " of the time after opening;

$\mathrm{I}_{\mathrm{j}} \times \mathrm{T}_{\mathrm{k}}=$ Effect of the interaction of level "j" of the inoculant with level " $k$ " of the time after opening;

$\mathrm{e}_{\mathrm{ijkl}}=$ experimental error associated with the plots that, by hypothesis, have normal distribution with zero mean and variance $\delta^{2}$.

Mean values referring to the sources of rehydration and the use of inoculant were compared by F-test. The breakdown of interactions was performed by Tukey's test. For all statistical procedures, $\alpha=0.05$ was adopted as the maximum tolerable limit for type I error. For exploratory data analysis by principal component analysis (PCA), the INFOSTAT software was used (Hammer, Harper, \& Ryan, 2001).

\section{Results and Discussion}

There was no interaction $(P=0.22)$ between rehydration source (water or whey) of corn with the use or not of the inoculant under and the times after opening the silos for temperature values during the aerobic exposure of the silage. There was interaction $(P=0.02)$ between rehydration sources and the use or not of the inoculant on silage temperature during aerobic exposure (Table 2). The lowest value was found in corn silage rehydrated with whey added with enzymaticbacterial inoculant. As for times $(P<0.01)$ after opening, maximum temperature was found after $63.33 \mathrm{~h}\left(27.80^{\circ} \mathrm{C}\right)$. However, this temperature did not exceed room temperature $+2^{\circ} \mathrm{C}$, an average of $30^{\circ} \mathrm{C}$. After $120 \mathrm{~h}$ of aerobic exposure of rehydrated corn silage, there was no break in stability, regardless of the treatment (Figure 1).

Table 2

Average temperature values during aerobic exposure of corn grain silages rehydrated with water or whey with the inclusion of enzymatic-bacterial inoculant

\begin{tabular}{ccccccccc}
\multirow{2}{*}{ Item } & \multirow{2}{*}{ Inoculant } & \multicolumn{2}{c}{ Rehydration } & & \multicolumn{3}{c}{ p-value } \\
\cline { 3 - 4 } Temperature & Water & Whey & SEM & Reid & Water & Whey \\
\cline { 3 - 4 } & Without & $27.56 \mathrm{Aa}$ & $27.76 \mathrm{Aa}$ & 0.07 & 0.72 & $<0.01$ & 0.02
\end{tabular}

SEM - standard error of the mean; $p$ - Probability. Means followed by different letters, uppercase in the same column, and lowercase in the same row, are significantly different by Tukey's test $(P<0.05)$.

Regarding the absence and presence of inoculant, corn silage without inoculant showed a mean temperature, throughout the period of aerobic exposure, $1.40 \%$ higher $(P$ $<0.01$ ) in relation to corn silage with inoculant (mean of $27.27^{\circ} \mathrm{C}$; Figure 2). This occurred because heterofermentative bacteria in the inoculant produced acetic acid, which is responsible for inhibiting the growth of
Clostridium bacteria. According to Kung et al. (2018), this result is justified by the growth of bacilli in silage with aerobic exposure associated with a $\mathrm{pH}$ above 5. Furthermore, the same authors argued that the increase in temperature of the ensiled material without inoculant is related to proliferation of undesirable microorganisms (yeasts, bacteria, filamentous fungi), causing the material to 
deteriorate. Thus, it is justified to use the enzymatic-bacterial inoculant in rehydrated corn grain silage because Lactobacillus buchneri, during carbohydrate metabolism, converts pyruvic acid into lactic acid and this in acetic acid under anaerobic conditions, that has a fungicidal action on silage (N. C. Silva et al., 2018).

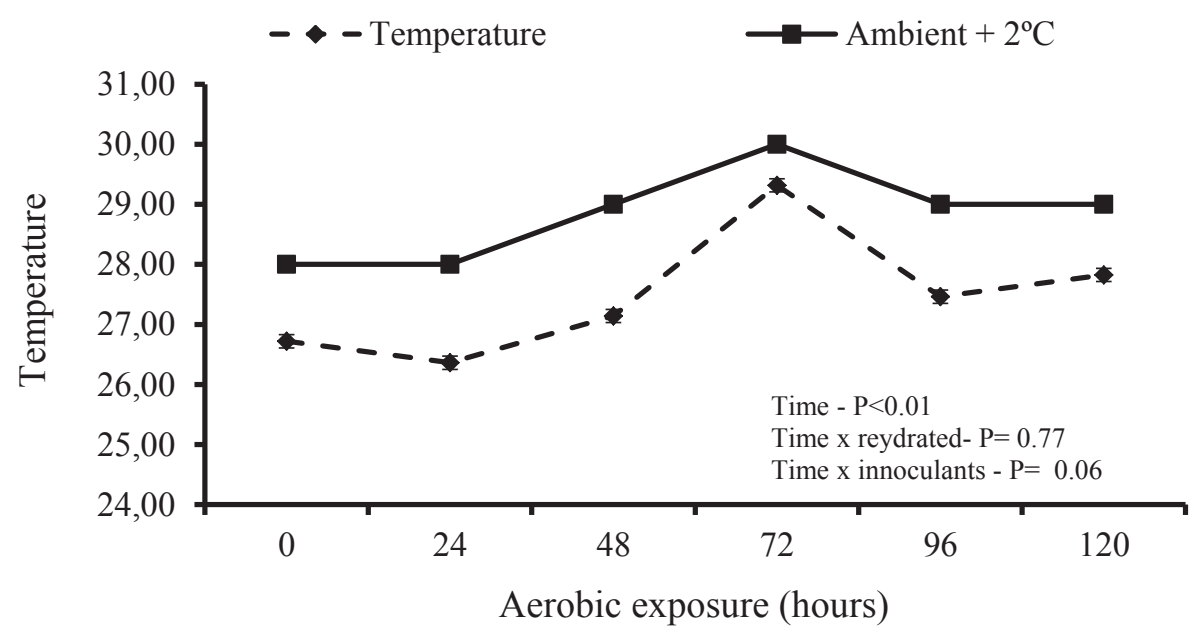

Figure 1. Temperature values of corn grain silages rehydrated with water or whey with inclusion of bacterial - enzymatic inoculant during aerobic stability.

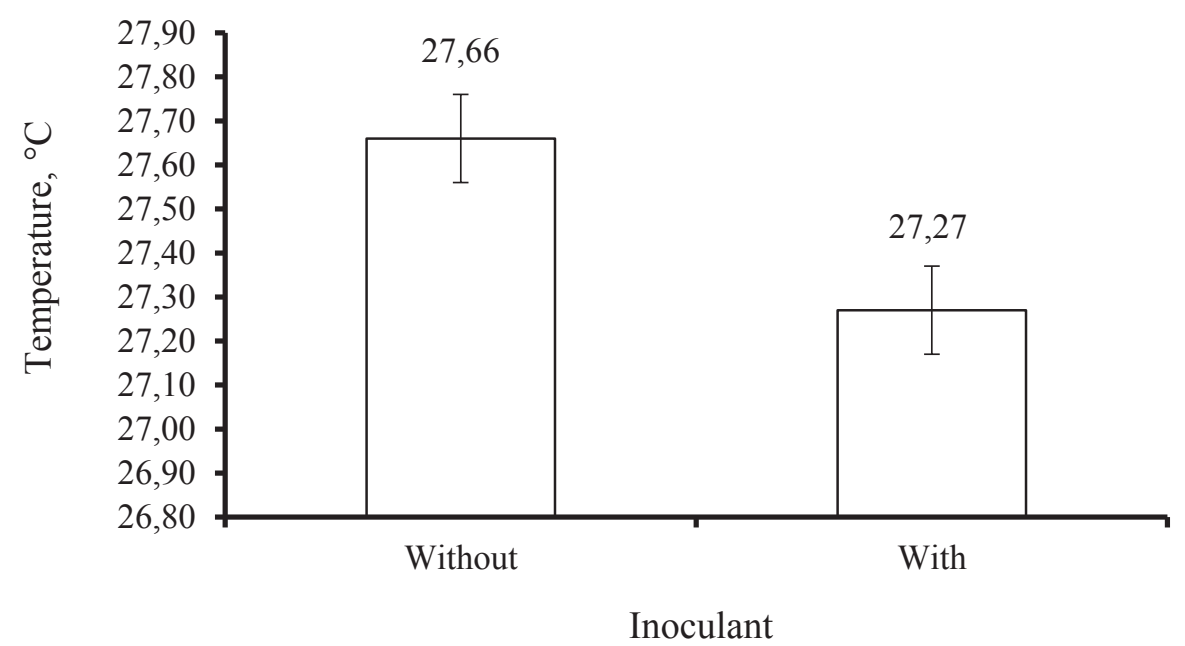

Figure 2. Isolated effect of bacterial-enzymatic inoculant on temperature values of corn grain silages rehydrated with water or whey during aerobic stability.

In this study, despite adjusting the moisture content to $35 \%$ during ensiling, there were no problems with breaking aerobic stability with less than 120 hours. This can be justified by climatic conditions in the semiarid region with high temperatures, favoring moisture losses during rehydrated corn silage management. For Ashbell, Weinberg, Hen and Filya (2002), breaking the aerobic stability of silage is a major problem in countries with hot climates and has as consequence problems associated with maintaining the nutritional 
value of the silage produced.

There was difference in DM losses between rehydrated corn silages without and with inoculant. DM losses were $37.51 \%$ higher in silage without inoculant compared to silage with inoculant (mean of $3.84 \%$ DM; Table 3). The reason for this difference is related to the increase in temperature of the ensiled mass as a result of unwanted fermentation in silage without inoculant. The inoculant contains lactic acid bacteria responsible for the production of lactic acid (N. C. Silva et al., 2018), which has the function of rapidly reducing the $\mathrm{pH}$ of the ensiled mass after closing the silo and DM losses.

\section{Table 3}

Fermentation characteristics of corn grain silages rehydrated with water or whey with the inclusion of enzymatic-bacterial inoculant

\begin{tabular}{|c|c|c|c|c|c|c|c|}
\hline \multirow{2}{*}{ Item } & \multirow{2}{*}{ Inoculant } & \multicolumn{2}{|c|}{ Rehydration } & \multirow[b]{2}{*}{ SEM } & \multicolumn{3}{|c|}{ p-value } \\
\hline & & Water & Whey & & Rehy & Ino & Rehy $x$ Ino \\
\hline \multirow{2}{*}{$\begin{array}{l}\text { DM losses, } \\
\% \text { DM }\end{array}$} & Without & 5.89 & 6.40 & \multirow{2}{*}{0.29} & \multirow{2}{*}{0.39} & \multirow{2}{*}{$<0.01$} & \multirow{2}{*}{0.38} \\
\hline & With & 3.84 & 3.84 & & & & \\
\hline \multirow{2}{*}{$\begin{array}{l}\text { Dry matter } \\
\text { recovery, \% }\end{array}$} & Without & 94.10 & 93.59 & \multirow{2}{*}{0.29} & \multirow{2}{*}{0.39} & \multirow{2}{*}{$<0.01$} & \multirow{2}{*}{0.38} \\
\hline & With & 96.15 & 96.15 & & & & \\
\hline \multirow{2}{*}{$\mathrm{pH}$} & Without & 4.23 Ba & 4.01 Ab & \multirow{2}{*}{0.02} & \multirow{2}{*}{$<0.01$} & \multirow{2}{*}{$<0.01$} & \multirow{2}{*}{$<0.01$} \\
\hline & With & $4.03 \mathrm{Aa}$ & $4.00 \mathrm{Aa}$ & & & & \\
\hline
\end{tabular}

DM - dry matter; SEM - standard error of the mean; $\mathrm{p}$ - Probability. Means followed by different letters, uppercase in the same column, and lowercase in the same row, are significantly different by Tukey's test $(P<0.05)$.

There was no difference between rehydration sources on DM losses $(P=0.39)$, mean of $4.99 \%$. Ávila et al. (2019) found higher DM losses from silage when rehydrating corn to $35 \%$ moisture with whey compared to water. The authors justified that lactose fermentation present in the acid whey may result in a decrease in the DM content by the fermentation process for greater production of organic acids in silage. Corn silage with inoculant increased $2.39 \%$ DM recovery.

There was interaction $(P<0.01)$ of rehydration sources and use of inoculant on $\mathrm{pH}$ values of the silage. The lowest $\mathrm{pH}$ values were verified in silages with the use of enzymaticbacterial inoculant and whey as rehydration source. This result occurred because whey is acidic ( $\mathrm{pH}=5.33)$. In addition, acid whey is a good source of rapidly fermentable carbohydrates (lactose) and its addition to corn silage results in rapid fermentation with an increase in lactic acid production as verified by Rezende et al. (2014). According to Muck et al. (2018) and Kung et al. (2018), the synthesis of lactic acid. whose pKa is 3.85. favors the rapid $\mathrm{pH}$ reduction of silage in relation to other organic acids (i.e., acetic, propionic and butyric acids). In general, silages presented $\mathrm{pH}$ values within the range considered adequate (3.5-4.5), showing good fermentation quality for rehydrated corn silage.

Corn rehydration using acid whey $(P$ $<0.01$ ) increased by $2.19 \%$ and $31.36 \%$ the DM and ash content compared to water, an 
average of $66.14 \%$ and $1.28 \%$, respectively. This result is justified by the content of DM (72.75 $\mathrm{g} \mathrm{kg}^{-1}$ as fed) and minerals in whey (Table 4).

Silage with inoculant showed DM content $0.64 \%$ higher in comparison to the silage without inoculant (mean of $666.6 \mathrm{~g} \mathrm{~kg}$ 1). There was a higher crude protein content in corn silage rehydrated with inoculant $(P$ $=0.02)$. The neutral detergent fiber content was not modified $(P=0.76)$ depending on the treatments, an average of $8.45 \%$. The highest levels of total carbohydrates $(P<0.01)$ were found in corn silages rehydrated with water without inoculantand whey with inoculant. Corn silages rehydrated with water with inoculant and whey without inoculant showed higher levels of total digestible nutrients $(P<0.01)$. In general, the use of inoculants in grain silage aims to increase the population of lactic acidproducing bacteria. This lactic acid will favor the $\mathrm{pH}$ reduction of the ensiled mass due to its low $\mathrm{pKa}$ value, acid dissociation constant $\mathrm{pKa}=$ 3.86 (Pahlow, Muck, Driehuis, Oude-Elferink, \& Spoelstra, 2003). This process can prevent the growth of bacteria, fungi and other unwanted microorganisms that ferment organic matter to produce gases, which represent DM losses. In this study, this contribution of the inoculant was verified because there was lower DM loss when compared to the control silage. This lower DM loss associated with the higher protein content in silage with inoculant is a novelty, since zein, present in the endosperm protein matrix, can be solubilized in lactic acid and acetic acid (N. C. Silva et al., 2018).

\section{Table 4}

Chemical composition of corn grain silages rehydrated with water or whey with inclusion of enzymebacterial inoculant

\begin{tabular}{|c|c|c|c|c|c|c|c|}
\hline \multirow{2}{*}{ Item } & \multirow{2}{*}{ Inoculant } & \multicolumn{2}{|c|}{ Rehydration } & \multirow[b]{2}{*}{ SEM } & \multicolumn{3}{|c|}{$\mathrm{p}$-value } \\
\hline & & Water & Whey & & Rehy & Ino & Rehy x Ino \\
\hline \multirow{2}{*}{ Dry matter } & Without & 658.4 & 674.9 & \multirow{2}{*}{2.1} & \multirow{2}{*}{$<0.01$} & \multirow{2}{*}{0.05} & \multirow{2}{*}{0.45} \\
\hline & With & 664.4 & 677.6 & & & & \\
\hline \multirow{2}{*}{ Ash } & Without & 12.9 & 18.0 & \multirow{2}{*}{0.9} & \multirow{2}{*}{$<0.01$} & \multirow{2}{*}{0.45} & \multirow{2}{*}{0.40} \\
\hline & With & 12.8 & 19.5 & & & & \\
\hline \multirow{2}{*}{ Crude protein } & Without & 70.0 & 74.7 & \multirow{2}{*}{4.6} & \multirow{2}{*}{0.94} & \multirow{2}{*}{0.02} & \multirow{2}{*}{0.28} \\
\hline & With & 86.3 & 80.9 & & & & \\
\hline \multirow{2}{*}{$\begin{array}{c}\text { Neutral } \\
\text { detergent fiber }\end{array}$} & Without & 87.9 & 83.0 & \multirow{2}{*}{5.6} & \multirow{2}{*}{0.25} & \multirow{2}{*}{0.83} & \multirow{2}{*}{0.76} \\
\hline & With & 90.8 & 82.5 & & & & \\
\hline \multirow{2}{*}{$\begin{array}{c}\text { Total } \\
\text { carbohydrates }\end{array}$} & Without & 855.1 Aa & $840.6 \mathrm{Ab}$ & \multirow{2}{*}{4.0} & \multirow{2}{*}{0.72} & \multirow{2}{*}{$<0.01$} & \multirow{2}{*}{$<0.01$} \\
\hline & With & $831.0 \mathrm{Ba}$ & 842.7 Aa & & & & \\
\hline \multirow{2}{*}{$\begin{array}{c}\text { Non-fiber } \\
\text { carbohydrates }\end{array}$} & Without & 767.1 & 757.6 & \multirow{2}{*}{7.8} & \multirow{2}{*}{0.51} & \multirow{2}{*}{0.13} & \multirow{2}{*}{0.07} \\
\hline & With & 740.2 & 760.2 & & & & \\
\hline \multirow{2}{*}{$\begin{array}{l}\text { Total digestible } \\
\text { nutrients }\end{array}$} & Without & $824.2 \mathrm{Bb}$ & 842.3 Aa & \multirow{2}{*}{4.9} & 098 & 006 & $<0$ \\
\hline & With & 851.9 Aa & 834.1 Ab & & & & \\
\hline
\end{tabular}

SEM - standard error of the mean; $p$ - Probability. Means followed by different letters, uppercase in the same column, and lowercase in the same row, are significantly different by Tukey's test $(P<0.05)$. 
There was no interaction $(P=0.30)$ between the sources of rehydration and the use of inoculants on the in vitro digestibility of DM (mean of $79.26 \%$; Table 5). The highest crude protein digestibility was observed in silage with inoculant. This improvement in DM and crude protein digestibility is associated with breaking the bonds of prolamins with starch (N. C. Silva et al., 2018). According to Hoffman et al. (2011), prolamins can be broken down during ensiling by enzymes of the plant and silage microorganisms through proteolysis and solubilization by acids during the fermentation process. The greater digestibility of dry matter and crude protein verified here was probably triggered by the greater availability of starch (Zinn, Owens, \& Ware, 2002), which in turn was induced by proteolysis during silage fermentation (N.C. Silva et al., 2018). For Junges et al. (2017), the proteolytic activity of bacteria present in the inoculant is the main responsible for proteolysis in rehydrated corn grain silage. Enzymes from grains, fungi and fermentation products contribute less to this breakdown of the protein matrix.

The inoculant resulted in higher neutral detergent fiber digestibility of corn silage, which seems to be related to the enzyme complex present in the additive. This enzyme complex contains cellulase and hemicellulase that can cause loosening of the structural arrangement of fibers present in the corn pericarp, favoring the action of fibrolytic bacteria (Martínez et al., 2020). This same behavior was verified in the acid detergent fiber digestibility, which was greater in corn silage rehydrated with whey combined with inoculant. There was no difference between treatments for indigestible dry matter content, with an average of $14.03 \%$. However, the indigestible fraction of neutral detergent fiber was $29.52 \%$ higher in corn silage rehydrated with whey (mean of $13.09 \%$ ). Regarding the indigestible fraction of acid detergent fiber, there was an effect of the use of inoculants. The presence of the inoculant reduced the indigestible fraction of acid detergent fiber in the silage, which is justified by the presence of the enzyme complex.

The method of Kaiser (1960) considers the principal components (PC) with eigenvalues equal to or above one (1). In Table 5 , the first five PCs explained $98.59 \%$ variance of the results based on the analysis of the correlation matrix of the original data. PCs 1 and 2 presented more than $70 \%$ (90.69\%) of the variance of the results, which confirms that these two PCs are of greater importance for data interpretation. 


\section{Table 5}

Digestibility and indigestible fraction of corn grain silages rehydrated with water or whey with inclusion of enzyme-bacterial inoculant

\begin{tabular}{|c|c|c|c|c|c|c|c|}
\hline \multirow{2}{*}{ Item } & \multirow{2}{*}{ Inoculant } & \multicolumn{2}{|c|}{ Rehydration } & \multirow[b]{2}{*}{ SEM } & \multicolumn{3}{|c|}{$p$-value } \\
\hline & & Water & Whey & & Rehy & $\operatorname{lno}$ & Rehy $x$ Ino \\
\hline \multicolumn{8}{|c|}{ In vitro digestibility, \% DM } \\
\hline \multirow{2}{*}{ Dry matter } & Without & 80.55 & 80.23 & \multirow{2}{*}{0.54} & \multirow{2}{*}{0.38} & \multirow{2}{*}{0.53} & \multirow{2}{*}{0.30} \\
\hline & With & 78.65 & 77.64 & & & & \\
\hline \multirow{2}{*}{ Organic matter } & Without & 68.64 & 69.57 & \multirow{2}{*}{1.9} & \multirow{2}{*}{0.47} & \multirow{2}{*}{0.28} & \multirow{2}{*}{0.81} \\
\hline & With & 66.11 & 67.94 & & & & \\
\hline \multirow{2}{*}{ Crude protein } & Without & $68.05 \mathrm{Ba}$ & $64.81 \mathrm{Bb}$ & \multirow{2}{*}{0.46} & \multirow{2}{*}{$<0.01$} & \multirow{2}{*}{$<0.01$} & \multirow{2}{*}{$<0.01$} \\
\hline & With & $70.37 \mathrm{Aa}$ & $69.90 \mathrm{Aa}$ & & & & \\
\hline \multirow{2}{*}{$\begin{array}{c}\text { Neutral } \\
\text { detergent fiber }\end{array}$} & Without & 65.58 & 64.51 & \multirow{2}{*}{0.58} & \multirow{2}{*}{0.99} & \multirow{2}{*}{$<0.01$} & \multirow{2}{*}{0.11} \\
\hline & With & 69.74 & 68.08 & & & & \\
\hline \multirow{2}{*}{$\begin{array}{l}\text { Acid detergent } \\
\text { fiber }\end{array}$} & Without & 45.93 & 40.28 & \multirow{2}{*}{0.43} & \multirow{2}{*}{0.03} & \multirow{2}{*}{$<0.01$} & \multirow{2}{*}{0.62} \\
\hline & With & 51.89 & 57.63 & & & & \\
\hline \multicolumn{8}{|c|}{ Indigestible fraction, \% DM } \\
\hline \multirow{2}{*}{ Dry matter } & Without & 11.27 & 14.05 & \multirow{2}{*}{2.1} & \multirow{2}{*}{0.09} & ח20 & 060 \\
\hline & With & 13.14 & 17.68 & & & 0.20 & 0.68 \\
\hline Neutral & Without & 11.57 & 13.03 & 136 & 0,4 & 031 & 270 \\
\hline detergent fiber & With & 8.65 & 13.16 & & & & \\
\hline Acid detergent & Without & 4.33 & 4.19 & 013 & 37 & ?ח९ & ג? \\
\hline fiber & With & 2.74 & 3.66 & 0.40 & ו & 0.02 & 0.24 \\
\hline
\end{tabular}

SEM - standard error of the mean; $p$ - Probability. Means followed by different letters, uppercase in the same column, and lowercase in the same row, are significantly different by Tukey's test $(P<0.05)$.

On PC 1, it was found that the in vitro digestibility of crude protein (0.9877) presented the highest eigenvector among the variables (Table 6), which means that this variable represented more than $70 \%$ variance.

On PC 2, the in vitro digestibility of organic matter and the in vitro digestibility of dry matter showed greater eigenvectors compared to the other variables. Despite presenting less variance of results in $\mathrm{PC} 3$, PC4 and PC 5, non-fiber carbohydrates and total carbohydrates were variables influenced by the treatments (Table 7). 
Table 6

Principal components (PCs), eigenvalues and percentage of variance associated with characteristics evaluated in corn grain silages rehydrated with water or whey with the inclusion of enzymatic-bacterial inoculant

\begin{tabular}{|ccc|}
\hline PC & Eigenvalue & Variance, \% \\
\hline 1 & 108.04 & 75.87 \\
\hline 2 & 21.11 & 14.83 \\
\hline 3 & 7.62 & 5.35 \\
\hline 4 & 1.96 & 1.38 \\
\hline 5 & 1.66 & 1.17 \\
\hline 6 & 0.89 & 0.63 \\
\hline 7 & 0.65 & 0.46 \\
\hline 8 & 0.28 & 0.20 \\
\hline 9 & 0.08 & 0.05 \\
10 & 0.06 & 0.04 \\
\hline 11 & 0.03 & 0.02 \\
12 & 0.01 & 0.01 \\
\hline 13 & 0.00 & 0.00 \\
\hline
\end{tabular}

Table 7

Principal component weighting coefficients retained considering the characteristics, in order of greatest importance

\begin{tabular}{|cccccc|}
\hline & \multicolumn{5}{c}{ Weighting coefficients (eigenvectors) } \\
\cline { 2 - 6 } Item & PC 1 & PC 2 & PC 3 & PC 4 & PC 5 \\
pH & -0.0002 & 0.0050 & 0.0160 & 0.0276 & -0.0375 \\
Demperature & -0.0075 & 0.0082 & 0.0167 & -0.0337 & 0.1200 \\
Ash & 0.0256 & 0.0508 & -0.0528 & -0.3072 & 0.4088 \\
Crude protein & 0.0059 & 0.0280 & 0.0003 & -0.1386 & 0.1470 \\
Ether extract & 0.0729 & 0.0197 & -0.2230 & -0.0833 & -0.0034 \\
\hline Total carbohydrates & -0.0106 & -0.0892 & -0.3251 & 0.2012 & 0.1574 \\
Non-fiber carbohydrates & -0.0183 & 0.0539 & $\mathbf{0 . 4 2 2 0}$ & -0.0165 & -0.2200 \\
Total digestible nutrients & -0.0118 & 0.0554 & $\mathbf{0 . 6 7 1 0}$ & 0.0001 & $\mathbf{0 . 6 1 2 4}$ \\
\hline In vitro dry matter digestibility & -0.0024 & -0.1370 & -0.3921 & 0.3063 & 0.5715 \\
\hline In vitro organic matter digestibility & -0.0667 & $\mathbf{0 . 1 6 6 9}$ & 0.1410 & $\mathbf{0 . 6 7 9 0}$ & -0.1182 \\
In vitro crude protein digestibility & $\mathbf{0 . 0 8 6 5}$ & $\mathbf{0 . 9 6 2 9}$ & -0.1665 & -0.0561 & 0.0628 \\
\hline Dry matter losses & -0.0765 & -0.0710 & 0.0604 & 0.1081 & -0.0136 \\
\hline
\end{tabular}


In general, the variables on the PC are the most important in the data set due to the largest eigenvector. However, it is important that these variables are biologically explainable in the general context of the results. Corn silages rehydrated with water or acid whey combined with the use of enzymatic-bacterial inoculants showed greater in vitro digestibility of crude protein and organic matter, whose eigenvectors are highly expressed in PC 1 and PC 2, respectively. Based on the behavior of the principal components, it is possible to verify the importance of acid whey as a source of rehydration of corn. This strategy avoids the disposal of acid whey into water courses or lakes.

\section{Conclusion}

Acid whey has great potential to be used for rehydrating and ensiling corn grain.

The use of the enzymatic-bacterial inoculant improved the fermentation characteristics, and chemical composition and in vitro digestibility of the corn grain silage rehydrated with water or whey.

\section{Acknowledgments}

The authors would like to thank the Fundação de Amparo à Pesquisa do Estado de Minas Gerais (FAPEMIG), Universidade Estadual de Montes Claros (Unimontes), Conselho Nacional de Desenvolvimento Científico e Tecnológico (CNPq), and Instituto Nacional de Ciência e Tecnologia (INCT - Ciência Animal) for their assistance with scholarships/ research. This study was financed in part by the Coordenação de Aperfeiçoamento de Pessoal de Nível Superior - Brasil (CAPES) -
Finance Code 001. The authors would like to thank the undergraduate students for their contribution towards the accomplishment of the research.

\section{References}

Ashbell, G., Weinberg, Z. G., Hen, Y., \& Filya, Y. (2002). The effects of temperature on the aerobic stability of wheat and corn silages. Journal of Industrial Microbiology and Biotechnology, 28(5), 261-263. doi: $10.1038 / \mathrm{sj} / \mathrm{jim} / 7000237$

Ávila, N. R. B., Dias e Silva, N. C., Leite, R. F., Barbosa, L. A., Florentino, L. A., \& Rezende, A. V. (2019). Caracterização da silagem de grão de milho reidratado associado ao resíduo de tilápia. Ciência Animal Brasileira, 20(e-50220), 1-12. doi: 10.1590/1089-6891v20e-50220

Bernardes, T. F., \& Rêgo, A. C. (2014). Study on the practices of silage production and utilization on Brazilian dairy farms. Journal of Dairy Science, 97(3), 1852-1861. doi: 10.3168/jds.2013-7181

Castro, L. P., Pereira, M. N., Dias, J. D. L., Lage, D. V. D., Barbosa, E. F., Melo, R. P.,... Pereira, R. A. N. (2019). Lactation performance of dairy cows fed rehydrated and ensiled corn grain differing in particle size and proportion in the diet. Journal of Dairy Science, 102(11), 9857-9869. doi: 10.31 68/jds.2019-16559

Daniel, J. L. P., Bernardes, T. B., Jobim, C. C., Schmidt, P., \& Nussio, L. G. (2019). Production and utilization of silages in tropical areas with focus on Brazil. Grass and Forage Science, 74(2), 188-200. doi: $10.1111 / \mathrm{gfs} .12417$ 
Detmann, E., Souza, M. A., Valadares, S. C., F., Queiroz, A. C., Berchielli, T. T., Saliba, E. O. S.,... Azevedo, J. A. G. (2012). Métodos para análise de alimentos. Visconde do Rio Branco, MG: Suprema.

Ferraretto, L. F., Silva, W. I., F., Fernandes, T., Kim, D. H., \& Sultana, H. (2018). Effect of ensiling time on fermentation profile and ruminal in vitro starch digestibility in rehydrated corn with or without varied concentrations of wet brewers grains. Journal of Dairy Science, 101(5), 46434649. doi: 10.3168/jds.2017-14329

Hammer, O., Harper, D. A. T., \& Ryan, P. D. (2001). PAST: Paleontological Statistics software package for education and data analysis. Palaeontol Electronica, 4(1), 1-9. Retrieved from https://palaeo-electronica. org/2001_1/past/past.pdf

Hoffman, P. C., Esser, N. M., Shaver, R. D., Coblentz, W. K., Scott, M. P., Bodnar, A. L., Schmidt, R. J., \& Charley, R. C. (2011). Influence of ensiling time and inoculation on alteration of the starch protein matrix in high-moisture corn. Journal of Dairy Science, 94(5), 2465-2474. doi: 10.3168/ jds.2010-3562

Jacovaci, F. A., Salvo, P. A. R., Jobim, C. C., \& Daniel, J. L. P. (2021). Effect of ensiling on the feeding value of flint corn grain for feedlot beef cattle: A meta-analysis. Revista Brasileira de Zootecnia, 50(1), e20 200111. doi: 10.37496/rbz5020200111

Jesus, M. A., Monção, F. P., Rigueira, J. P., Rocha, V. R., Jr., Gomes, V. M., Delvaux, N. A., Jr.,... Santos, A. S. (2021). Effects of microbial inoculant and fibrolytic enzymes on fermentation quality and nutritional value of BRS capiaçu grass silage. Semina: Ciências Agrárias, 43(3),
1-10. doi: 10.5433/1679-0359.2021v42 n3Supl1p1837

Jobim, C. C., Nussio, L. G., Reis, R. A., \& Schmidt, P. (2007). Avanços metodológicos na avaliação da qualidade de forragem conservada. Revista Brasileira de Zootecnia, 36(1), 101-119. doi: 10.1590/ S1516-35982007001000013.

Johnson, R. A. E., \& Wichern, W. D. (2007). Applied multivariate statistical analysis (6nd ed.). Pearson Prentice Hall.

Junges, D., Morais, G., Spoto, M. H. F., Santos, P. S., Adesogan, A. T., Nussio, L. G., \& Daniel, J. L. P. (2017). Short communication: influence of various proteolytic sources during fermentation of re-constituted corn grain silages. Journal of Dairy Science, 100(11), 9048-9051. doi: 10.31 68/jds.2017-12943

Kaiser, H. F. (1960). The application of electronic computers to factor analysis. Educational and Psychological Measurement, 20(1), 141-151. doi: 10.11 77/001316446002000116

Kung, L., Jr., Shaver, R. D., Grant, R. J., \& Schmidt, R. J. (2018). Silage review: interpretation of chemical, microbial, and organoleptic components of silages. Journal of Dairy Science, 101(1), 4020-4033. doi: 10.3168/ jds.2017-13909

Martínez, J. R. P. F., Huerta, A. G., López, D. J. P., Cuevas, R. S., Salem, A. Z. M., RoblesJimenez, L. E. \& Gonzalez-Ronquillo, M. (2020). Effect of xylanase, cellulase and natural maguey extract on the chemical composition of corn silage and in vitro rumen gas production. International Journal of Agriculture and Natural Resources, 47(1), 23-34. doi: 10.7764/ ijanr.v47i1.2128 
Mombach, M.A., Pereira, D. H.,Pina, D.S., Bolson, D. C., \& Pedreira, B. C. (2019). Silage of rehydrated corn grain. Arquivo Brasileira de Medicina Veterinária e Zootecnia, 71(3), 959-966. doi: 10.1590/1678-41629676.

Muck, R. E., Nadeau, M. G., McAllister, T. A., Contreras-Govea, F. E., Santos, M. C., \&, Kung, L., Jr. (2018). Silage review: recent advances and future uses of silage additives. Journal of Dairy Science, 101(5), 3980-4000. doi: 10.3168/jds.2017-13839

National Research Council (2001). Nutrient requirements of dairy cattle (7nd rev. ed.). Washington, DC: National Academy Press.

Pahlow, G., Muck, R. E., Driehuis, F., OudeElferink, S. J. W. H., \& Spoelstra, S. F. (2003). Microbiology of ensiling. In D. R. Buxton, R. E. Muck, \& J. H. Harrison (Eds.), Silage science and technology (pp. 3193). Madison, WI: American Society of Agronomy.

Rezende, A. V., Rabelo, C. H. S., Sampaio, L. M., Härter, C. J., Lorentino, L. A., Paula, D. W., \& Braga, T. C. (2016). Ensiling a dry bakery by-product: effect of hydration using acid whey or water associated or not at urea. Revista Brasileira de Saúde e Produção Animal, 17(4), 626-641. doi: 10.1590/S15 19-99402016000400007

Rezende, A. V., Rabelo, C. H. S., Veiga, R. M., Andrade, L. P., Härter, C. J., Rabelo, F. H. S.,... Reis, R. A. (2014). Rehydration of corn grain with acid whey improves the silage quality. Animal Feed Science and Technology, 197(1), 213-221. doi: 10. 1016/j.anifeedsci.2014.07.009

Silva, C. M., Amaral, P. N. C., Baggio, R. A., Tubin, J. S. B., Conte, R. A., Pivo, J. C. D.,... Paiano,
D. (2016). Estabilidade de silagens de grãos úmidos de milho e milho reidratado. Revista Brasileira de Saúde Produção Animal, 17(3), 331-343. doi: 10.1590/S15 19-99402016000300001

Silva, N. C., Nascimento, C. F., Nascimento, F. A., Resende, F. D., Daniel, J. L. P., \& Siqueira, G. R. (2018). Fermentation and aerobic stability of rehydrated corn grain silage treated with different doses of Lactobacillus buchneri or a combination of Lactobacillus plantarum and Pediococcus acidilactici. Journal of Dairy Science, 101(5), 4158-4167. doi: 10. 3168/jds.2017-13797

Tilley, J. M. A., \& Terry, R. A. (1963). A twostage technique for the in vitro digestion of forage crops. Journal of the British Grassland Society, 18(2), 104-111. doi: 10.1111/j.1365-2494.1963.tb00335.x

Valadares, S. C., F., Costa e Silva, L. F., Giobelle, M. P., Rotta, P.P., Marcondes, M. I., Chizzotti, M. L., \& Prados, L. F. (2016). Exigências nutricionais de zebuínos puros e cruzados (3a ed.). Recuperado de https://brcorte. com.br/livro2016br.

Valente, T. N. P., Detmann, E., Queiroz, A. C., Valadares, S. C., F., Gomes, D. I., \& Filgueiras, J. F. (2011). Evaluation of rumen degradation profiles of forages using bags made from different textiles. Revista Brasileira de Zootecnia, 40(11), 2565-2573. doi: 10.1590/S1516-359820 11001100039

Zinn, R. A., Owens, F. N., \& Ware, R. A. (2002). Flaking corn: Processing mechanics, quality standards, and impacts on energy availability and performance of feedlot cattle. Journal Animal Science, 80(5), 1145-1156. doi: 10.2527/2002.8051145x 
